\title{
Business Management Development Model For "Cireng Ceu Iin" Enterprises In Padasuka Village, Baros District, Serang Regency
}

\author{
Khaeruman $^{1 *}$, M. Ilmi Syiraf ${ }^{2}$, Defi Mugfiroh ${ }^{3}$, Yeny Safriyana ${ }^{4}$, Fariha Maulani ${ }^{5}$, Difa Ramadani \\ Nurhidayati ${ }^{6}$ \\ 1,2,3,4,5,6 Bina Bangsa University, Indonesia \\ ${ }^{*}$ Corresponding author: \\ Email: khaeruman.oce@gmail.com
}

\begin{abstract}
.
Marketing is a business function that identifies current unmet wants and needs and manages their size, determines which target markets the organization can best serve, and determines the appropriate range of products, services and programs to serve those markets. So marketing acts as a liaison between the needs of the community and the pattern of industrial responses.This community service activity is carried out at the home of the business actor who has the address. The method used in the implementation of community service activities is business assistance.The purpose of this method is the participatory-lecture method,discussion-information and continued with direct training on making business management development models for business actors "Cireng Ceu Iin" in Padasuka Village, Baros District, Serang Regency.In a business, it is better to plan carefully both in terms of future prospects and the management system that can be done to manage the business in question. In addition, it is necessary to take into account the prospect of competition, market segmentation and the smooth running of its business. Especially for the management of the Cireng-making business, it is necessary to pay attention to the availability of raw materials in the form of sago and flour which must be processed into dough. Setting the selling price is one of the factors that must be considered in a business. Prices must be realistic but do not forget the capital spent to carry out the business in question.
\end{abstract}

Keywords: Management Development, Business Actor

\section{INTRODUCTION}

Nowadays, the need for varied food and high nutritional value has increased. One of the potential food commodities that should be considered to meet this need is regional specialties. So far, in rural areas, farmers only sell a few parts, in this case the processed ingredients are made into ingredients for making cireng, namely sago and flour mixed with the prepared ingredients.Knowing the uses and what products can be produced will certainly encourage everyone to take advantage and earn higher incomes. Wheat can be processed into various types of food that are delicious and also have high nutritional value. The number of processed products from flour is the main reason why we try to process flour and need to be developed in its processing. The choice of sago and flour is also very appropriate considering the benefits and uses of sago and flour are quite broad, especially for the food industry. Of the various types of food. Cireng is a product that is suitable for everyone, besides the process of making it is quite easy, cireng is a snack that is familiar to most of the population in Indonesia.In this day and age where our society is very critical of the quality of healthy food, especially foods that are snacks or light snacks. Therefore, in people's habits where when working on an activity, hobby or even during breaks are usually inseparable from the name snacks or light snacks which are usually purchased in packaged form from various shops, retails, supermarkets or even from stands. or kiosks that are often on the side of the road. For this reason, we intend to make a type of cireng snack made from flour that is safe for consumption because it is hygienic and clean in the production process and of course it must be affordable by the general public.

There are various kinds of business land that can be done, including the processing of cireng-making business, namely: Cipuk (Cireng Crackers), Crispy Cilok, Crispy Cireng and Nugget. The cireng marketing mechanism involves several parties including producers, distributors and consumers, especially marketing in 
this field.This industrial business has developed for quite a long time considering that cireng itself is a food made for souvenirs or as snacks. Marketing is the most decisive job in any business activity. Without proper and correct marketing, the results of cultivation that have been carried out will be in vain. Because marketing activities involve the flow of products from producers to consumers, marketing creates important jobs for the community. The marketing aspect is an important aspect. If the marketing mechanism works well, then all parties involved will benefit. Therefore, the role of marketing agencies becomes very important. Marketing institutions for developing countries, which are characterized by weak marketing of agricultural products that will determine the market mechanism. The problem faced in the marketing of this cireng is the lack of availability of processing raw materials from raw materials into flour. To obtain these raw materials, entrepreneurs must obtain them from various regions, so that factors related to marketing will be increasingly disrupted, namely marketing channels that should be short become long.

There are many factors that influence the marketing of this cireng, both internal and external factors. Therefore, it is very important to analyze internal and external factors to get the right strategy for cireng marketing. It is hoped that this marketing strategy can provide direction to cireng marketing so that consumer satisfaction is achieved and marketers benefit and can improve their standard of living.From the description above, we chose to produce and develop a packaged cireng business that can be supplied to collaborating shops or can be sold alone. We deliberately chose sago and flour as raw materials because these two are widely used in the case of mixed cireng snacks and the taste is mostly very popular and liked by our society. With the above reasons, we finally decided to develop business management for business actors in packaging named "Cireng Ceu Iin" with the hope that all consumers who eat these manufactured snacks will feel maximum pleasure and enthusiasm in carrying out their activities.

\section{Marketing}

According to Kotler (1997:8) marketing is a social and managerial process by which individuals and groups obtain their needs and desires in creating, offering and exchanging things of value with one another. So marketing acts as a liaison between the needs of the community and the pattern of industrial responses (in this case including the industry in the agricultural sector). Meanwhile, according to Swastha and Basu (1991:78) marketing is the overall system of business activities aimed at planning, determining, promoting and distributing needs to existing buyers. The marketing concept holds that the social and economic reason for an organization's existence is to satisfy consumer needs and wants in accordance with the company's goals. The most important thing in marketing is to focus on the wants and desires of consumers so that the organization can differentiate its products from those offered by competitors, integrate all organizational activities, including products to satisfy these needs, and achieve long-term goals for the organization by satisfying these needs.

The four marketing strategies are:

- Products $\rightarrow$ Managing product elements including proper planning and development marketed by the company is very important. Strategy is needed to change existing products, propagate new ones and take other actions that affect product assortment.

- Price $\rightarrow$ In determining the price, management must determine the right base price for its product. Management must determine a strategy related to price, payment of freight and various variables related to price.

- Promotion $\rightarrow$ Promotion is an element used to inform and persuade the market about the company's new product.

- Distribution $\rightarrow$ Marketing intermediaries are basically environmental factors that are beyond the reach of the company, a marketing executive still has a wide range of motion when he deals with intermediaries.

\section{Competition}

An entrepreneur must be able to see and take advantage of existing opportunities so that the business he runs does not fail in the middle of the road. Competition with other companies will be overcome with well-planned and well-thought-out steps, which include efficiency and improving the quality of the products we make, which in this case the cireng production process, is carried out quickly without neglecting the taste 
and appearance of the cireng.Market segmentation can be formulated as a process where marketers place different market groups (heterogeneous) into one group that has similarities (homogeneous), (Amirullah, 2002:10). Efficiency can be done by using skilled workers or workers who have been trained in the manufacture of cassava chips. Starting from the preparation of raw materials to slicing followed by frying. In the production of food ingredients, it is very important to pay attention to taste and appearance. High taste without regard to appearance, will be less successful, and vice versa. Elegant and unique product packaging will provide its own selling point. In fact, most of the products are packaged, almost $40 \%$ of the production cost is for packaging, while the rest is for raw materials and labor.

\section{Marketing strategy}

Kotler (2005:69) suggests that strategy is a defined, broad and integrated plan that links the advantages of a company's strategy with environmental challenges and which is designed to ensure that the main objectives of the company can be achieved through proper implementation by the organization.Marketing strategy is basically a comprehensive, integrated, and unified plan in the field of marketing, which provides guidance on activities to be carried out to achieve marketing objectives. In other words, marketing strategy is a set of goals and objectives, policies and rules that give direction to marketing efforts from time to time at each level and its references and allocations, especially in response to the ever-changing competitive environment and conditions.

Basically, a marketing strategy also includes a product strategy and a market strategy where all of these are efforts made to get used to regularly choosing markets and what products to market based on considerations of the environmental situation. Strategy making is always related to the development of the company's vision, mission, strategic objectives and policies, thus strategic planning must analyze the company's strategic factors (strengths, weaknesses, opportunities, and threats) in current conditions (Rangkuti, 2002:18). The marketing strategy consists of integrated marketing elements (4P's of the marketing mix, namely product, price, promotion, place) which are always evolving in line with the movements and changes in the marketing environment as well as changes in consumer behavior. If the marketing objectives describe where to go, the marketing strategy shows the route to be taken to achieve these goals.

\section{Marketing Environment Analysis}

The marketing environment is the actors and forces that are outside the management function. Thus, it will affect the ability of marketing management to develop and maintain successful transactions with its target customers. The marketing environment includes external factors, namely:

1. Consumer

Consumers influence the industry through their ability to push down prices, demand for better quality or services, and play a role in competing against one another.

\section{Supplier}

Suppliers can influence the industry by their ability to raise prices or lower the quality of goods or services purchased.

3. Technology

Every company involves a large number of technologies. Everything a company does involves a certain type of technology, despite the fact that one or more technologies may appear to dominate the product or production process.

4. Competitors

A company in the long term will be able to survive if it successfully develops a strategy to deal with a competitive structure among companies in the industry, the threat of the entry of new entrants, the threat of substitute products, the bargaining power of buyers and suppliers, these five forces together will determine intensity of competition and potential profitability of firms in an industry

\section{Setting the Price}

The selling price is determined by taking into account the price of raw materials, worker wages, production processes, packaging, marketing and if necessary, promotion and transportation costs are also taken into account. All prices that have been identified can be calculated until a minimum unit price can be 
obtained. Then we can determine the selling price after calculating the profit we want to get.Pricing is very necessary to standardize sales, so that there will be no significant gap between product prices that consumers have to pay directly and product prices after going through distributors.In setting the selling price, we must also be realistic. If it is set too high then consumers will reconsider buying our product and furthermore they will run to other similar products. This of course does not want to happen. For this reason, it is necessary to take into account the selling price of products from other manufacturers. Therefore, pricing must be carried out according to the sales area that is the target of selling Cireng products.

\section{Reasons for Choosing Cireng Business}

Our reason for choosing products from cireng to be used as a home-based business industry is based on considerations that have been seen among the community, namely cireng snacks are foods that are widely recognized by people and are favored by many people. From small children to adults. However, multi-tasting cireng is rarely found, so we took the initiative to open it.Sago and flour have long been known to the public as raw materials for various purposes, one of which is as raw materials for processed foods. Cireng in this case Cireng in this case the type of product: Cipuk (Cireng Kerupuk), Crispy Cilok, Crispy Cireng and Nugget, for example, this food has long been a snack or snack that many people like. However, it does not rule out the emergence of large businesses that produce cireng with various flavors.

\section{METHOD}

This community service activity is carried out at the home of the business actor whose address is Kp. Cikokosan nyomplong, RT/RW. 009/002 Baros District, Serang Regency, Banten. This activity will be held on July 20 - 31, 2021. The method used in implementing community service activities is business assistance. The purpose of this method is the participatory-lecture method, discussion-information and continued with direct training on making business management development models for business actors "Cireng Ceu Iin" in Padasuka Village, Baros District, Serang Regency.

\section{Business Plan}

1. Short Term Plan

This cireng production business aims to train us as producers on how to build and start a business well so that we can produce the best quality products, in the sense that it also adds to our knowledge of independent entrepreneurship. It is also expected as soon as possible to reach a Break Even Point (BEP).

\section{Medium Term Plan}

This cireng production business is expected to generate large profits and grab the attention of the public so that it can become the product of choice that they buy and consume.

\section{Long Term Plan}

In the future, we will see how the community responds to our production because it will be our rationale for options to add other flavors of chips such as chocolate flavored cireng, greentea and so on so that with the increasing number of varieties of these chips, it is expected to generate greater profits. the greater it is. In terms of distribution, of course, we will always look for wider marketing gaps in order to increase the number of product sales.

\section{DISCUSSION}

\section{Production Aspect}

Production Aspect

1. Product

The products we produce have a wide variety of cireng, namely:

$>$ Cipuk (Cireng Crackers)

$>$ Crispy Cilok

$>$ Crispy Cireng

$>$ Nuggets

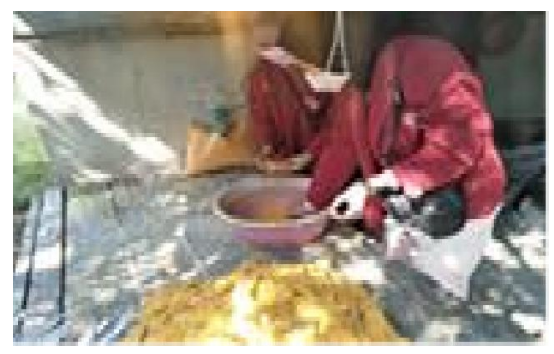


Our products are made with a high level of hygiene and cleanliness and do not use chemicals that can damage health such as borax, formalin, artificial coloring or other hazardous materials.

2. Production Plan

Our production plan is as follows:

a. Product design

We will make packaging designs that are as attractive and practical as possible to carry around so that they can become the choice of consumers of our products.

b. Place of business

In the meantime, we use the private house method as a place of processing so that it is sent to the seller, and if there are consumers who want to buy, we will directly deliver the cireng. In the future, it is hoped that if negotiations have been reached with other parties, they will immediately send the stock of goods to the buyer.

c. Supervision

As a producer, we always open communication with consumers, so that if there are criticisms or suggestions, we will immediately follow up and pay attention. For product quality, we will always monitor and pay attention.

3. Production process

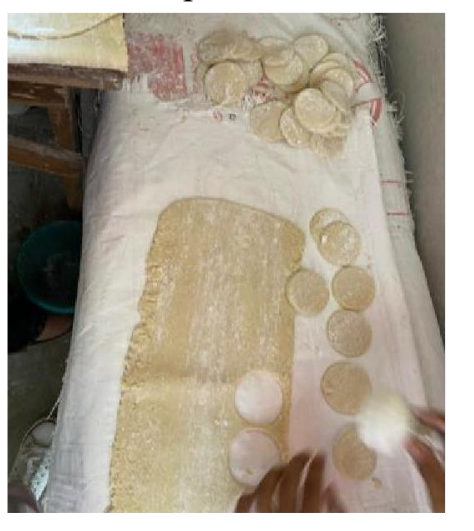

Making cireng is very simple and does not require special skills, but care must be taken in kneading the dough and making techniques. Must use good quality sago and flour ingredients and also good manufacturing techniques, it will produce a delicious and tender cireng.

How to make Crispy Cireng.

- Prepare the ingredients for sago and flour

- Mix the prepared ingredients

- Prepare spices such as salt, seasonings and sauces

- Then mix into it

- Process the ingredients and spices until they become cireng dough

- Widen the dough to make it easier during the printing process

- Print dough

- After being printed, the dough is boiled for 10 minutes in boiling water

- After 10 minutes the dough is drained

- Sprinkle the dough into the breadcrumbs/bread flour

- Crispy Cireng is ready to be shipped and marketed.

- How to consume crispy cireng by frying.

\section{Environmental Aspect}

1. Place of business

In the meantime, we use private vehicles as a place to stock goods so that if there are consumers who want to buy, we directly deliver the chips to the consumer. Positioning is the act of designing the company's image and value offered so that customers in a segment understand and appreciate the company's position in relation to competitors. The positioning task consists of three steps: recognizing competitive advantages that may be exploited, selecting the most appropriate and effectively signaling to the market about the position the company will choose (Suyanto, 2007: 73).

In the future, it is hoped that if negotiations have been reached with the hospital canteen, we will immediately send the stock of goods to the canteen.

2. Marketing strategy analysis

a. Segmentation $\rightarrow$ activities that are a segment of Cireng's business are the lower middle to upper segment.

b. Targeting $\rightarrow$ activities that become the target market are all people who like snacks with cassava as basic ingredients. 
c. Positioning $\rightarrow$ is an activity that wants to create an image in the minds of consumers as the producer of the most desirable cassava chips.

3. Distribution Channel

a. Producers - Consumers $\rightarrow$ Consumers transact directly to the place of manufacture (producer)

b. Manufacturers - Retailers - Consumers $\rightarrow$ Manufacturers offer products to retailers and retailers who deliver them to consumers.

4. Business location

As for the business location considerations, they are in the Baros Market, Lightning, Rau Market,

Pandeglang areas.

Marketing Aspect

1. Target Market

Our current target market is the area where we work, namely Pasar Baros, Petir, Pasar Rau, Pandeglang with the scope of buyers being employees and household families.

2. Competitors/Competitors

There are many competitors in the business of selling this snack, including the many other brands that are sold in retail stores around this area. But believe that the best quality can win the hearts of potential consumers to choose the cireng produced.

3. Target Buyers

With a very affordable selling price for one package of cireng, the target buyers are all people who are in the Padasuka Village Area, and Banten Province in general.

4. Marketing Strategy

Some of our marketing strategies are:

- Publication in the form of giving testers to employees and passersby in the area so that potential consumers can try the taste and quality of this cireng so that they are expected to choose to buy this cireng product.

- Spread the promotion to everyone about this cireng. According to Tjiptono (2010:291) promotion is a marketing activity that seeks to disseminate information, influence or persuade and increase the target market for the company and its products so that they are willing to accept, buy and deserve the products offered by the company concerned.

- Dissemination of information about this product through word of mouth to strengthen the brand image of this cireng product in the minds of consumers and potential consumers.

- Spread of social media promoting online

SWOT analysis

The SWOT analysis of this business opportunity is:

1. Strength

a. Has a delicious, soft and savory taste

b. Made from quality and healthy raw materials

c. Has a strong packaging, clean and easy to carry around

d. Have an affordable selling price

2. Weakness

a. Have competitors who have the same type of production

b. The fluctuating level of production raw material prices that can change

c. Certain community factors prefer to make their own snacks rather than buying them

d. Distribution costs that can sometimes swell due to congestion

3. Opportunities

a. All levels of society like snacks, especially those made from sago and flour

b. Targeting people who need practical snacks

c. People like affordable snacks

4. Threats 
Because almost all levels of society really like snacks, the competition factor with fellow snack producers becomes very fierce so that if we are caught off guard with the quality and amount of the selling price, it is very possible for our products to be overtaken and not competitive. Therefore, quality should be controlled and paid attention to and in terms of calculating the amount of the profit ratio, it should not be too large because it is better to make a little profit but sell a lot of goods than big profits but sell a little.

\section{CONCLUSION}

From the description above, a common thread can be drawn in the cireng business, including that in a business it is better to plan it carefully both in terms of future prospects and the management system that can be done to manage the business in question. In addition, it is necessary to take into account the prospect of competition, market segmentation and the smooth running of its business. Especially for the management of the Cireng-making business, it is necessary to pay attention to the availability of raw materials in the form of sago and flour which must be processed into dough. Setting the selling price is one of the factors that must be considered in a business. Prices must be realistic but do not forget the capital spent to carry out the business in question.All of that the key is good management, strong desire, enthusiasm to move forward and not afraid to fall and discipline and don't forget to pray to the Creator for the success of the business being carried out.

\section{ACKNOWLEDGMENTS}

The author would like to thank all circles and the community for their support and encouragement during the process until the completion of this service. It is hoped that it can be used as reading material to add insight and views of readers about the business management development model for "Cireng Ceu Iin" business actors, as well as a source of reference and information for the same size of service as well as comparative studies and assistance for business actors.

\section{REFERENCES}

[1] Amirullah. 2002. Consumer Behavior. Yogyakarta : Graha Ilmu

[2] Kotler. 1997. Marketing Management Analysis, Planning, and Control. Volume 1. ter. Hendro Teguh. Jakarta: Eternal Independent Association.

[3] 2005. Marketing Management vol 2: Issue 11. ter. Benjamin Molan. PT Intan Sejati Klaten. Jakarta.

[4] Rangkuti, Freedy. 2005. SWOT Analysis of Business Case Dissecting Techniques, Jakarta : Gramedia Pustaka Utama

[5] Suyanto, 2007, Indonesia's Top Brand Marketing Strategy, Yogyakarta: CV. Andi. Offset

[6] Swastha, Basu. 1991. Principles of Marketing, Third Edition. First Printing. Publisher Liberty Yogyakarta.

[7] Tjiptono, Fandy. 2010. Marketing Strategy. Yogyakarta: Andy Offset 